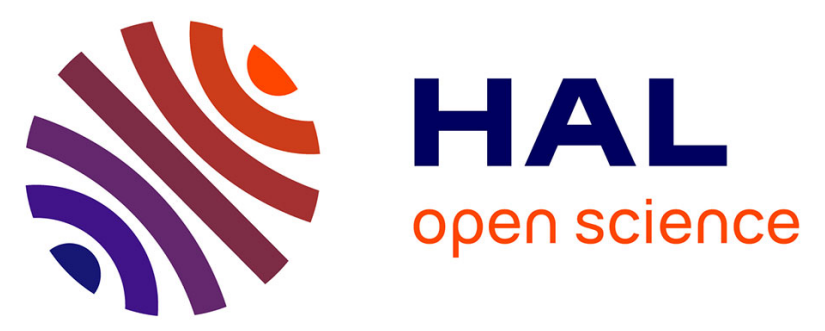

\title{
Gastritis due to Helicobacter pylori, an unusual cause of chronic diarrhoea in HIV infected patients
}

D. Lambert, C. Rouger, M.D. Diebold, F. Ramaholimihaso, C. Boulagnon, Y. Nguyen, Maxime Hentzien, R. Jaussaud, F. Bani-Sadr

\section{> To cite this version:}

D. Lambert, C. Rouger, M.D. Diebold, F. Ramaholimihaso, C. Boulagnon, et al.. Gastritis due to Helicobacter pylori, an unusual cause of chronic diarrhoea in HIV infected patients. Médecine et Maladies Infectieuses, 2014, 44 (7), pp.337-338. 10.1016/j.medmal.2014.06.005 . hal-02883077

\section{HAL Id: hal-02883077 https://hal.science/hal-02883077}

Submitted on 28 Jun 2020

HAL is a multi-disciplinary open access archive for the deposit and dissemination of scientific research documents, whether they are published or not. The documents may come from teaching and research institutions in France or abroad, or from public or private research centers.
L'archive ouverte pluridisciplinaire HAL, est destinée au dépôt et à la diffusion de documents scientifiques de niveau recherche, publiés ou non, émanant des établissements d'enseignement et de recherche français ou étrangers, des laboratoires publics ou privés. 


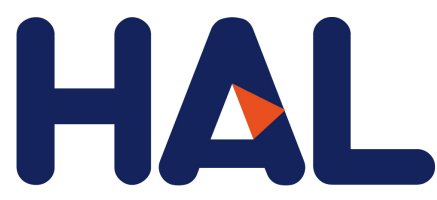

archives-ouvertes

\section{Gastritis due to Helicobacter pylori, an unusual cause of chronic diarrhoea in HIV infected patients}

D. Lambert, C. Rouger, M.D. Diebold, F. Ramaholimihaso, C. Boulagnon, Y. Nguyen, Maxime Hentzien, R. Jaussaud, F. Bani-Sadr

\section{- To cite this version:}

D. Lambert, C. Rouger, M.D. Diebold, F. Ramaholimihaso, C. Boulagnon, et al.. Gastritis due to Helicobacter pylori, an unusual cause of chronic diarrhoea in HIV infected patients. Medecine Et Maladies Infectieuses, Elsevier, 2014, 44 (7), pp.337-338. 10.1016/j.medmal.2014.06.005 . hal02883077

\section{HAL Id: hal-02883077 \\ https://hal.archives-ouvertes.fr/hal-02883077}

Submitted on 28 Jun 2020

HAL is a multi-disciplinary open access archive for the deposit and dissemination of scientific research documents, whether they are published or not. The documents may come from teaching and research institutions in France or abroad, or from public or private research centers.
L'archive ouverte pluridisciplinaire HAL, est destinée au dépôt et à la diffusion de documents scientifiques de niveau recherche, publiés ou non, émanant des établissements d'enseignement et de recherche français ou étrangers, des laboratoires publics ou privés. 


\section{Gastritis due to Helicobacter pylori, an unusual cause of chronic diarrhoea in HIV infected patients}

\section{Gastrite à Helicobacter pylori, cause inhabituelle de diarrhée chronique chez les patients infectés par le VIH}

Keywords: Helicobacter pylori; HIV infection; Chronic diarrhea; Gastritis

Mots clés : Helicobacter pylori ; Infection par le VIH ; Diarrhée chronique ; Gastrite

Gastric colonization with Helicobacter pylori (HP) induces asymptomatic gastritis in all infected individuals but only a minority develop any apparent clinical symptoms of this colonization such as a peptic ulcer disease or a distal gastric cancer $[1,2]$. Diarrhea has rarely been described as a clinical manifestation of HP infection [3,4]. We report 2 cases of chronic diarrhea in HIV patients with evidence of symptomatic HP gastritis; the outcome was favorable after HP eradication.

A 65-year-old female patient was referred to our unit in July 2012 for diarrhea ongoing for 24-weeks, and weight loss $(4 \mathrm{~kg})$. She complained of chronic, profuse watery diarrhea ( 8 to 10 stools per day). She was diagnosed with HIV-1 infection in 1993 and had a history of Pneumocystis jiroveci pulmonary infection in 2003. She had been receiving highly active antiretroviral therapy (HAART) since 2003 and she had been treated with tenofovir, emtricitabine, ritonavir, and fosamprenavir since 2006. The CD4 cell count and the HIV RNA level were $686 \mathrm{cells} / \mathrm{mm}^{3}$ and less than 50 copies $/ \mathrm{mL}$, respectively. The patient was apyretic and had no laboratory evidence of inflammation (C-reactive protein $<5 \mathrm{mg} / \mathrm{dL}$ ). Stool examination (screening for bacteria and protozoa) performed on 3 occasions was normal and toxin testing for Clostridium difficile was negative. Colonoscopy, colic biopsies, and gastroscopy were also normal. Gastric biopsies revealed gastritis with infiltration of the gastric mucosa by neutrophils causing focal pit abscesses and numerous mononuclear cells in the lamina propria, intestinal metaplasia, and high HP inoculum on the surface epithelium.

A 64-year-old male patient was admitted in May 2012 in our unit for watery chronic diarrhea ongoing for 8 weeks and abdominal pain. He was diagnosed with HIV-1 infection in 1996 with at that time a cutaneous Kaposi's sarcoma. He had received HAART since 1996, and had been taking lamivudine, abacavir, and nevirapine since January 2010. The CD4 cell count and the HIV RNA level were 1,090 cells $/ \mathrm{mm}^{3}$ and less than 50 copies $/ \mathrm{mL}$, respectively. Stool examination (screening for bacteria and protozoa) and colonoscopy with systematic biopsies and gastroscopy were normal. Gastric biopsies, as in the previous case, revealed gastritis lesions of the gastric mucosa in both antrum and corpus: neutrophils pit abscesses; interstitial mononuclear cells infiltration, and a high HP inoculum.

The 2 patients received HP eradication therapy (omeprazole $40 \mathrm{mg}$, clarithromycin $1,000 \mathrm{mg}$, amoxicillin 2,000 mg daily) for 10 days that was followed by a complete resolution of diarrhea at 1 year and 18 months of follow-up, respectively. A $13 \mathrm{C}$ urea breath test performed 1 month after the end of HP eradication therapy was negative for both patients.

A dramatic decrease in the frequency of digestive diseases, mainly opportunistic pathologies, has been observed in AIDS patients with the improvement of immunity due to HAART [5]. However, HP infection has increased even with the use of HAART [6]. HIV positive patients infected by HP had a higher mean CD4 count than those without HP [5-7]. It is well known that CD4 cells play a role in inducing gastritis and this gastritis might be a mechanism by which HP colonization is enhanced. The higher acid secretion in patients treated with HAART contrasting with gastric hypoactivity observed in advanced stages of HIV infection, associated with increased CD4 cell counts may allow an effective inflammatory response and provide the favorable conditions needed for HP growth [5]. Furthermore, gastric lesions due to HP are usually more severe in HIV-positive patients than in HIV negative patients $[5,6]$.

HIV infection was controlled in both of our patients for several years with a CD4 cell count above $500 / \mathrm{mm}^{3}$. The absence of other etiologies and the dramatic response to HP eradication suggest the role of HP in chronic diarrhea. The mechanism of diarrhea is unknown. However, the acute phase of colonization with HP may be associated with considerable inflammation of both the proximal and distal stomach mucosa. This phase is often associated with hypochlorhydia, which can last for months. A fasting hypergastrinemia is then frequently observed $[1,2]$. In our patients, gastric biopsies were characterized by considerable active inflammation with a very high HP inoculum and neutrophils pit abscesses.

Clinicians should consider gastritis due to HP infection in HIV infected patients, particularly those with high CD4 counts, presenting with chronic diarrhea. 


\section{Disclosure of interest}

The authors have not supplied their declaration of conflict of interest.

Contribution of authors: C. Rouger, MD. Diebold, F. Ramaholimihaso managed the patients. D. Lambert, MD. Diebold, F. Ramaholimihaso, C. Boulagnon, Y. Nguyen, M. Hentzien, R. Jaussaud, and F. Bani-Sadr drafted the article.

\section{References}

[1] Algood HMS, Cover TL. Helicobacter pylori persistence: an overview of interactions between H.pylori and host immune defenses. Clin Microbiol Rev 2006;19:597-613.

[2] Kusters JG, van Vliet AHM, Kuipers EJ. Pathogenesis of Helicobacter pylori infection. Clin Microbiol Rev 2006;19:449-90.

[3] Sud A, Ray P, Bhasin DK, Wanchu A, Bambery P, Singh S. Helicobacter pylori in Indian HIV infected patients. Trop Gastroenterol Off J Dig Dis Found 2002;23:79-81.

[4] Abu-Zekry MA, ES Hashem M, Ali AA, Mohamed IS. Frequency of Helicobacter pylori infection among Egyptian children presenting with gastrointestinal manifestations. J Egypt Public Health Assoc 2013;88:74-8.

[5] Nkuize M, De Wit S, Muls V, Arvanitakis M, Buset M. Upper gastrointestinal endoscopic findings in the era of highly active antiretroviral therapy. HIV Med 2010;11:412-7.

[6] Olmos M, Araya V, Pskorz E, Quesada EC, Concetti H, Perez H, et al. Coinfection: Helicobacter pylori/human immunodeficiency virus. Dig Dis Sci 2004;49:1836-9.

[7] Korać M, Brmbolić B, Salemović D, Ranin J, Stojsić Z, Jevtović D, et al. Diagnostic esophago-gastro-duodenoscopy (EGD) in patients with AIDS-related upper gastrointestinal abnormalities. Hepatogastroenterology 2009;56:1675-8.

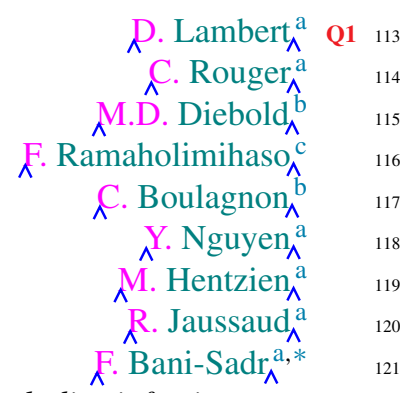

a Unité de médecine interne et des maladies infectieuses et $\mathrm{Q}_{122}$ tropicales, hôpital Robert-Debré, université

Champagne-Ardenne, Reims, France

${ }^{\mathrm{b}}$ Laboratoire central d'anatomie et de cytologie pathologiques, hôpital Robert-Debré, université

Champagne-Ardenne, Reims, France

c Service d'hépato-gastro-entérologie, hôpital Robert-Debré, université Champagne-Ardenne, Reims, France

Corresponding author. E-mail addresses: fbanisadr@chu-reims.fr, firouze.bani-sadr@tnn.aphp.fr (F.Bani-Sadr)

Received 25 March 2014

Received in revised form 2 June 2014

Accepted 2 June 2014 